\title{
Influence of Thermo-Electrical Property of Materials on Powder Mixed Electrical Discharge Machining
}

\section{S. Jeavudeen}

Department of Mechcnial Engineering, B.S. Abdurrahman Crescent Institute of Science \& Technology Chenna India

H. Siddhi Jailani

Department of Mechcnial Engineering B.S. Abdurrahman Crescent Institute of Science \& Technology Chennai India

\section{Murugan}

School of Mechcnial Engineering Vellore of Institute \& Technology, VIT, Vellore. India
Powder Mixed Electrical Discharge Machining (PMEDM) is considered as one of the viable methods to machine the materials which are hard and tough but with appreciable thermo-electrical properties. In PMEDM, it has been established that machinability is enhanced by adding additives in the form of fine powders in the spark gap of EDM process. In this investigation, the role of the thermo-electrical properties of workpiece on PMEDM process has been studied. Materials with distinct thermoelectric property, namely Mild Steel and Aluminium are taken as workpiece with Alumina as additive powder for the PMEDM process. Experiments have been conducted with Taguchi L9 Orthogonal Array (OA) with Material Removal Rate (MRR) and Tool Wear Index (TWI) as responses. Gap current, duty cycle and flow rate of powder mixed dielectric liquid have been taken as process parameters at 3 levels with circular copper rod of $12 \mathrm{~mm}$ diameter as tool electrode. Determination of the influence of properties of the workpiece on the machinability has been performed using a custom made PMEDM set-up. ANOVA and main effect plot of data means for the aforementioned conditions have been analysed. The results are noteworthy with significant influence of the properties of the workpiece on the machinability of PMEDM process.

Keywords: PMEDM, L9 OA, MRR, TWI, Thermo-electric property

\section{INTRODUCTION}

Electrical discharge machining (EDM), also called as spark erosion technique, is one of the feasible manufacturing techniques used to machine the materials which are hard and tough to be manufactured in the conventional machining process. The ease with which it makes complex and intricate shapes on harder materials with high aspect ratio, makes EDM suitable for machining hardened steel, cemented carbide and conductive ceramics[1] on the workpiece material with fairly good electric and thermal conductivity [2]. Due to this, EDM has replaced the conventional machining process such as milling of heat treated tool steels, where the hardness of the workpiece are fairly larger [3]. But the process time involved in EDM is so longer that it makes the machining very slower. Over these years, researchers made several attempts to achieve satisfactory machining rate in EDM and subsequently the following variants of EDM comes into exists viz., dry EDM, EDM with ultrasonic vibration, Powder mixed EDM (PMEDM), EDM in water etc., [4]. In all these processes, EDM is basically involved together with a newer mechanism to enhance the machining rate of the EDM process. These newer trends of EDM aimed at influencing the characteristics of the dielectric fluid,

Received: December 2018, Accepted: March 2019

Correspondence to: Jeavudeen Shiek

B.S. Abdurrahman Crescent Institute of Science \&

Technology, Chennai - India.

E-mail: shiek.zia@gmail.com

doi: $10.5937 /$ fmet1903518J

(C) Faculty of Mechanical Engineering, Belgrade. All rights reserved thereby machinability could be improved. Among the types of EDM process, PMEDM is one of the widely used techniques, wherein the additive powders are added into the spark gap. Under the influence of electric field, these powders are arranged between the electrodes in zig-zag manner resulting in the formation of bridge, which in turn alters the breakdown strength of the dielectric fluid resulting in earlier spark [5-7]. The additive powders ranging from Silicon to Graphite powder were found to be enhancing the material removal rate in PMEDM process [8] where these artificial contaminations found to be aiding the breakdown characteristics of the dielectric fluid [9]. Murray et al observed that the physical and the electrical properties of the gap debris also played a role in altering the breakdown strength of the dielectric fluid [10].

Use of nano $\mathrm{TiO}_{2}$ powder with rotary tool was also observed to be increasing the machining characteristics of hot work steel [11]. Jeavudeen et al experimented that the addition of additive powders resulted in the lowering of breakdown voltage which also coupled with the reduction of gap voltage [12]. It was reported that the phenomenon of the occurrence of earlier spark in PMEDM resulted in the machining of materials at lower gap voltage, thereby enhancing the material removal rate and tool wear index $[13,14]$.

To reinforce the concept of PMEDM, Gangadharudu et al tried powders with different thermo-electric properties as additives and reported that the process of adding powder additives enhanced the machinability [15]. Literature available shows that powders with varied concentration [16], particle size, density and 
different thermo-electrical properties of the powders [17] affect the performance of PMEDM, but very little study has been done on the effect of the property of work piece on the performance in PMEDM process. Hence the present work focuses on the effect of thermoelectric property of the workpiece on the machinability of PMEDM.

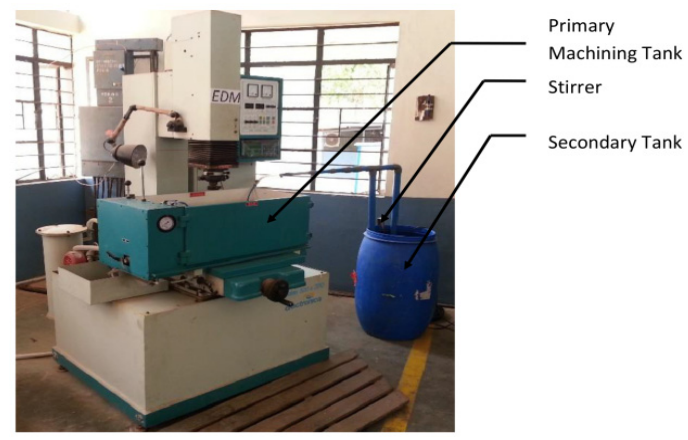

Figure 1. PMEDM set-up

Table 1. Thermo-physical Properties of the Additive Powders

\begin{tabular}{|l|c|c|c|}
\hline Property & Mild Steel & Copper & Aluminium \\
\hline $\begin{array}{l}\text { Electrical } \\
\text { Conductivity (s/m) }\end{array}$ & $0.699 \times 10^{7}$ & $5.85 \times 10^{7}$ & $3.5 \times 10^{7}$ \\
\hline $\begin{array}{l}\text { Thermal } \\
\text { conductivity } \\
(\mathrm{W} / \mathrm{mK})\end{array}$ & 54 & 401 & 205 \\
\hline Density $(\mathrm{g} / \mathrm{cc})$ & 7.85 & 8.96 & 2.70 \\
\hline Melting point $\left({ }^{\circ} \mathrm{C}\right)$ & 1,425 & 1,083 & 660 \\
\hline
\end{tabular}

Table 2. Machining Conditions

\begin{tabular}{|c|c|c|c|c|}
\hline \multirow{2}{*}{ Factor } & \multirow{2}{*}{ Notation } & \multicolumn{3}{|c|}{ Level } \\
\cline { 3 - 5 } & & 1 & 2 & 3 \\
\hline Duty Cycle (\%) & A & 70 & 80 & 90 \\
\hline Current (A) & B & 15 & 20 & 25 \\
\hline Dielectric Flow rate (lpm) & C & 3.5 & 5.0 & 6.5 \\
\hline
\end{tabular}

\section{EXPERIMENTS}

\subsection{Experimental Work}

To study the effect of thermo-electrical properties of the workpiece, when machined using the PMEDM process, the existing EDM set-up was modified. The custom made experimental set-up was devised as shown in the Figure. 1, which consisted of: EDM (Electronica) with inbuilt

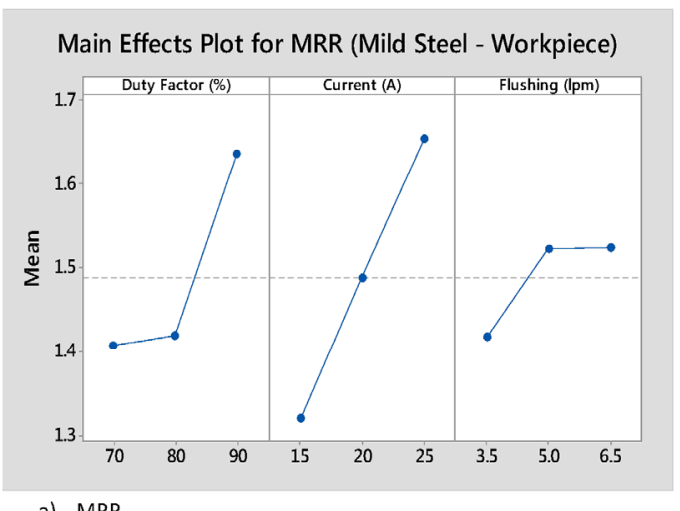

a) MRR primary machining tank to recirculate the EDM fluid, a secondary tank being additionally used to mix the powder with the EDM fluid, a stirrer to ensure the homogeneity of the mixture, a flow control valve to meter the mixture and a centrifugal pump to deliver the powder mixed dielectric into the spark gap. Mild steel and Aluminium plate with distinct properties (Table.1) of dimensions 100 $\mathrm{mm}$ X $100 \mathrm{~mm}$ with $10 \mathrm{~mm}$ thickness were taken as workpiece and a circular copper rod of $12 \mathrm{~mm}$ diameter as tool electrode. Alumina at 44 microns with a concentration of $2 \mathrm{~g} /$ litre was taken as powder additive.

Table 3. L9 Orthogonal Array with Factors and Levels

\begin{tabular}{|c|c|c|c|c|}
\hline & & Duty Factor & Current & $\begin{array}{l}\text { Dielectric } \\
\text { Flow rate }\end{array}$ \\
\hline & Unit & $\%$ & A & $1 \mathrm{pm}$ \\
\hline \multirow{9}{*}{ 武 } & 1 & 70 & 15 & 3.5 \\
\hline & 2 & 70 & 20 & 5.0 \\
\hline & 3 & 70 & 25 & 6.5 \\
\hline & 4 & 80 & 15 & 5.0 \\
\hline & 5 & 80 & 20 & 6.5 \\
\hline & 6 & 80 & 25 & 3.5 \\
\hline & 7 & 90 & 15 & 6.5 \\
\hline & 8 & 90 & 20 & 3.5 \\
\hline & 9 & 90 & 25 & 5.0 \\
\hline
\end{tabular}

\subsection{Experimental Design}

From the experimental conditions stated, duty cycle, gap current and dielectric flushing rate were taken as three factors with three levels for each of the parameters as shown in the Table.2. Taguchi L9 OA (Orthogonal Array) was used for the design of the experiments, which is widely used to attain optimization in industries [18]. OA and the levels for each of the factors are given in Table.3.

Table 4. Experimental Results for L9 OA

\begin{tabular}{|c|c|c|c|c|}
\hline \multirow{2}{*}{ Trials } & \multicolumn{2}{|c|}{ Mild Steel } & Aluminium & \\
\cline { 2 - 4 } & MRR & \multirow{2}{*}{ TWI } & MRR & \multirow{2}{*}{ TWI } \\
\cline { 2 - 2 } & grams/min & & grams/min & \\
\hline 1 & 1.2221 & 10.7269 & 1.4362 & 23.0008 \\
\hline 2 & 1.3590 & 9.2965 & 1.4520 & 16.2418 \\
\hline 3 & 1.6397 & 5.6620 & 1.7541 & 7.8120 \\
\hline 4 & 1.3163 & 15.9440 & 1.3712 & 30.0512 \\
\hline 5 & 1.5085 & 10.4864 & 1.6677 & 12.6212 \\
\hline 6 & 1.4335 & 7.8168 & 1.6486 & 10.6427 \\
\hline 7 & 1.4221 & 28.0519 & 1.5692 & 38.8808 \\
\hline 8 & 1.5976 & 12.0326 & 1.6700 & 12.5246 \\
\hline 9 & 1.8909 & 7.2338 & 1.9683 & 10.6292 \\
\hline
\end{tabular}

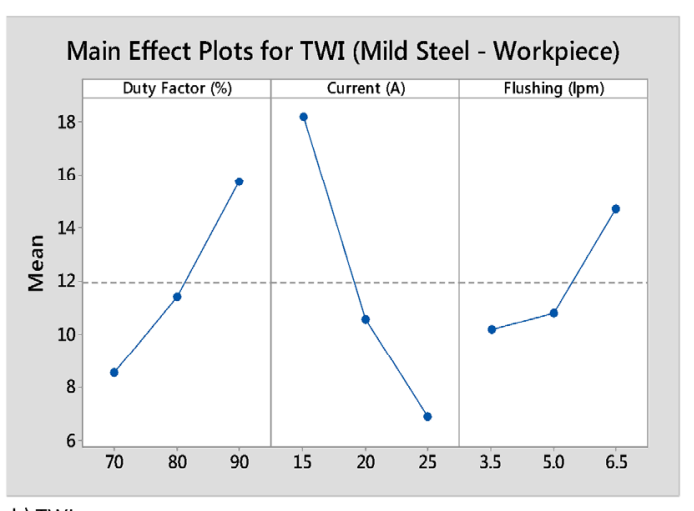

b) TWI

Figure 2. (a \& b) Effect of Process parameters on Machinability of Mild steel workpiece 


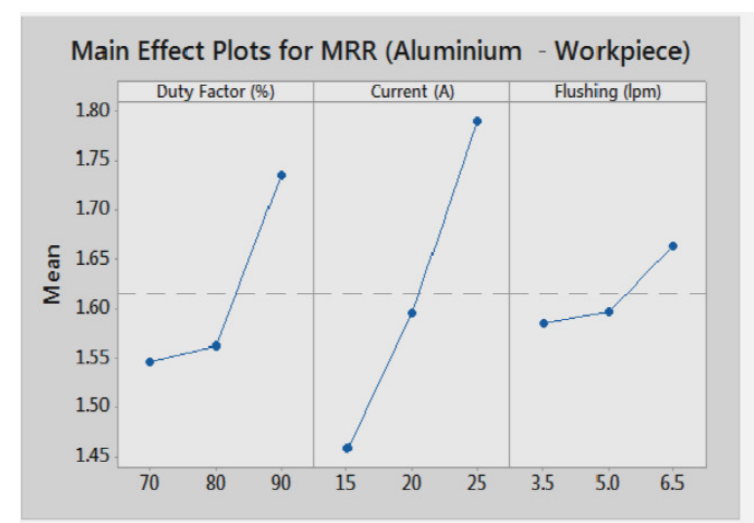

a) MRR

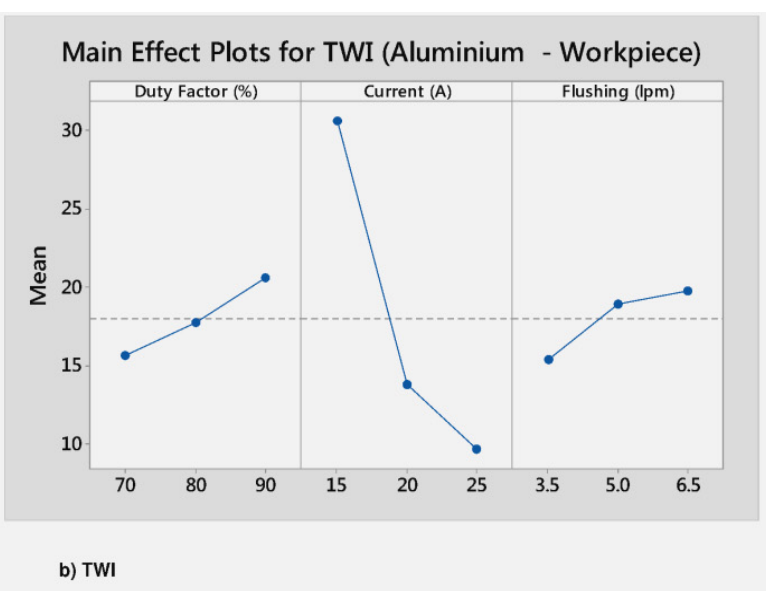

b) TWI

Figure 3. (a \& b) Effect of Process parameters on Machinability of Aluminium workpiece

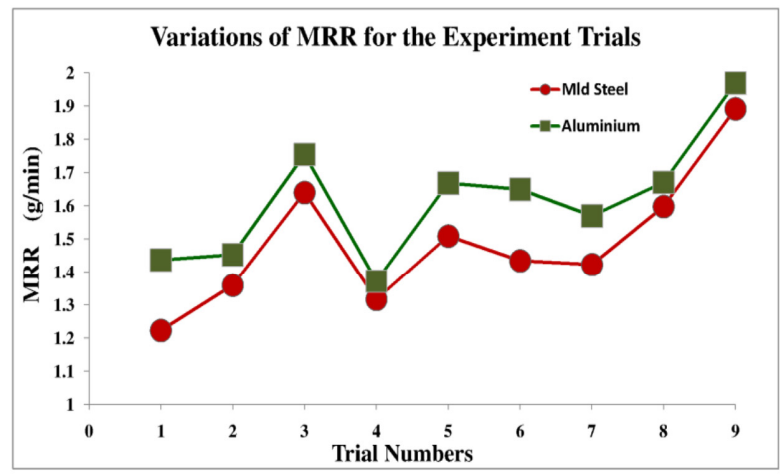

a) MRR

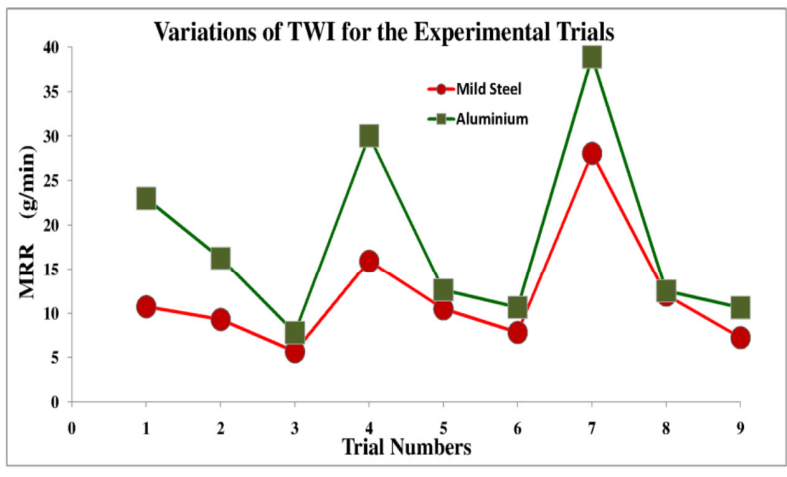

b) TWI

Figure 4. (a \& b) Variation of Machining Characteristics for Aluminium and Mild Steel

Main effect plots were used to estimate the effect of each of the factors on the machinability at various levels. The effect of each of these parameters on the machinability of workpiece was determined by means of ANOVA analysis as it gives significant process parameters [19]. In each of the trials, a total of three experiments were conducted to ascertain the accuracy of the result. The output responses such as MRR and TWI are presented in the Table 4. Material removal rate (MRR) and Tool wear rate (TWR) were calculated by measuring the difference in the mass of the workpiece and the tool before and after machining per unit time and the Tool wear index (TWI) was estimated by calculating the ratio of MRR per unit TWR.

\section{RESULTS AND DISCUSSION}

When additive powder like alumina is added to the dielectric fluid, it gets energised and forms a zig-zag fashion bridging the gap between the electrode surfaces causing early spark [20]. This eventually lowers the breakdown voltage of the dielectric fluid used [12]. This lowered breakdown voltage helps in enhancing the machinability of the PMEDM process. The effect of thermoelectric property of workpiece materials on PMEDM process is discussed as below.

\subsection{Effect of workpiece Properties on Improving the MRR}

From the experimental observations, it was found that the process parameters had considerable effect in increasing the MRR of both Aluminium and Mild Steel. From Figures 2 (a) \& 3 (a), the rise in electrical parameters, viz., duty factor and current causes more electrical energy to be conducted between the sparks resulting in higher MRR [21]. Favourable electrical parameters coupled with the gap contamination by the way of flushing of powder mixed dielectric liquid into the electrode gap also enhances the MRR in both Aluminium and Mild Steel workpieces. This is attributed to the fact that the higher flushing rate significantly increases the gap contamination and dictates the quality of the electric discharge between the electrodes [22]. From Figure 4 (a) it is obvious that the machinability of Aluminium work piece is better than that of the Mild Steel work piece for all the nine experiment trials, irrespective of the process parameters and their levels. Higher thermal and electrical conductivity of Aluminium makes it easy to melt and vaporize in the spark gap, thereby enhancing the MRR in Aluminium than in Mild Steel whose properties are relatively lower [23, 24].

Table 5. Results of Analysis of Variance for TWI - Mild Steel

\begin{tabular}{|c|c|c|c|c|c|}
\hline Source & DoF & SS & MS & F Ratio & $\begin{array}{c}\% \text { Contri- } \\
\text { bution }\end{array}$ \\
\hline A & 2 & 79.1267 & 39.5633 & 1.6210 & $21.69 \%$ \\
\hline B & 2 & 200.5237 & 100.2618 & 4.1080 & $54.97 \%$ \\
\hline C & 2 & 36.3017 & 18.1509 & 0.7437 & $9.95 \%$ \\
\hline Error & 2 & 48.8126 & 24.4063 & & $13.38 \%$ \\
\hline Total & 8 & 364.7647 & & & \\
\hline
\end{tabular}


The general effect of the process parameters on individual performance has also been analysed using ANOVA, which is shown in Tables 5-8. Among the selected parameters, current has predominant effect in aiding the MRR of both Aluminium and Mild steel workpieces (Table Nos 6 and 8), which is followed by the duty factor. Also, among the factors selected for the experiment trials, electrical factors, viz., current and duty factor have played a major role in enhancing the machinability of the materials used. The role of higher dielectric discharge in the spark could possibly hamper the machinability by creating instability in the discharge zone [25]. Subsequent to the enhancement of MRR in the PMEDMed process, the surface topology of the machined surface has been observed to be free from micro-cracks, craters etc., [26]. It is evident from Fig.5 that the PMEDMed surface of Aluminium workpiece is relatively smoother than that with the normal EDMed surface. Normal EDMed surface is marked with deep crater with matte appearance.

Table 6. Results of Analysis of Variance for MRR - Mild Steel

\begin{tabular}{|c|c|c|c|c|c|}
\hline Source & DoF & SS & MS & F Ratio & $\begin{array}{c}\% \\
\text { Contribution }\end{array}$ \\
\hline A & 2 & 0.1003 & 0.0502 & 1.6210 & $31.16 \%$ \\
\hline B & 2 & 0.1679 & 0.0840 & 4.1080 & $52.16 \%$ \\
\hline C & 2 & 0.0221 & 0.0110 & 0.7437 & $6.85 \%$ \\
\hline Error & 2 & 0.0317 & 0.0158 & & $9.83 \%$ \\
\hline Total & 8 & 0.3219 & & & \\
\hline
\end{tabular}

\subsection{Effect of workpiece properties on improving the TWI}

The selected process parameters were found to enhance the tool wear index of both Aluminium and mild Steel workpieces. Form figures 2 (b) \& 3 (b), it is observed that the duty factor and the dielectric discharge rate have considerable effect on TWI of both the workpieces. However, increase in gap current between the electrodes has resulted in lowering the TWI. This is due to the fact that at higher current, the spark intensity also will be larger resulting in higer tool wear and thus it affects the TWI [27]. But in general, the machinability in terms of TWI has been found to be better in Aluminium workpiece than in Mild Steel as depicted in Figure. 4 (b). This is possibly due to the addition of powder additives, i.e., PMEDM, into the spark gap, which eventually lowers the breakdown strength of the liquid dielectric, resulting in higher MRR per unit tool wear [12]. In the ANOVA analysis, gap current has played a significant effect on TWI of both the workpieces, followed by duty factor and dielectric flushing (Tables 5 and 7). Lower melting point and higher thermal conductivity of Aluminium seem to have enhanced the machinability better than the Mild steel workpiece.

Table 7. Results of Analysis of Variance for TWI Aluminium

\begin{tabular}{|c|c|c|c|c|c|}
\hline Source & DoF & SS & MS & F Ratio & $\begin{array}{c}\% \\
\text { Contribution }\end{array}$ \\
\hline A & 2 & 37.7363 & 18.8681 & 1.6210 & $4.29 \%$ \\
\hline B & 2 & 739.5774 & 369.7887 & 4.1080 & $84.00 \%$ \\
\hline C & 2 & 32.6878 & 16.3439 & 0.7437 & $3.71 \%$ \\
\hline Error & 2 & 70.4863 & 35.2432 & & $8.01 \%$ \\
\hline Total & 8 & 880.4877 & & & \\
\hline
\end{tabular}

Table 8. Results of Analysis of Variance for MRR Aluminium

\begin{tabular}{|c|c|c|c|c|c|}
\hline Source & DoF & SS & MS & F Ratio & $\begin{array}{c}\% \\
\text { Contribution }\end{array}$ \\
\hline A & 2 & 0.0658 & 0.0329 & 1.6210 & $24.26 \%$ \\
\hline B & 2 & 0.1664 & 0.0832 & 4.1080 & $61.35 \%$ \\
\hline C & 2 & 0.0108 & 0.0054 & 0.7437 & $3.97 \%$ \\
\hline Error & 2 & 0.0283 & 0.0141 & & $10.42 \%$ \\
\hline Total & 8 & 0.2712 & & & \\
\hline
\end{tabular}
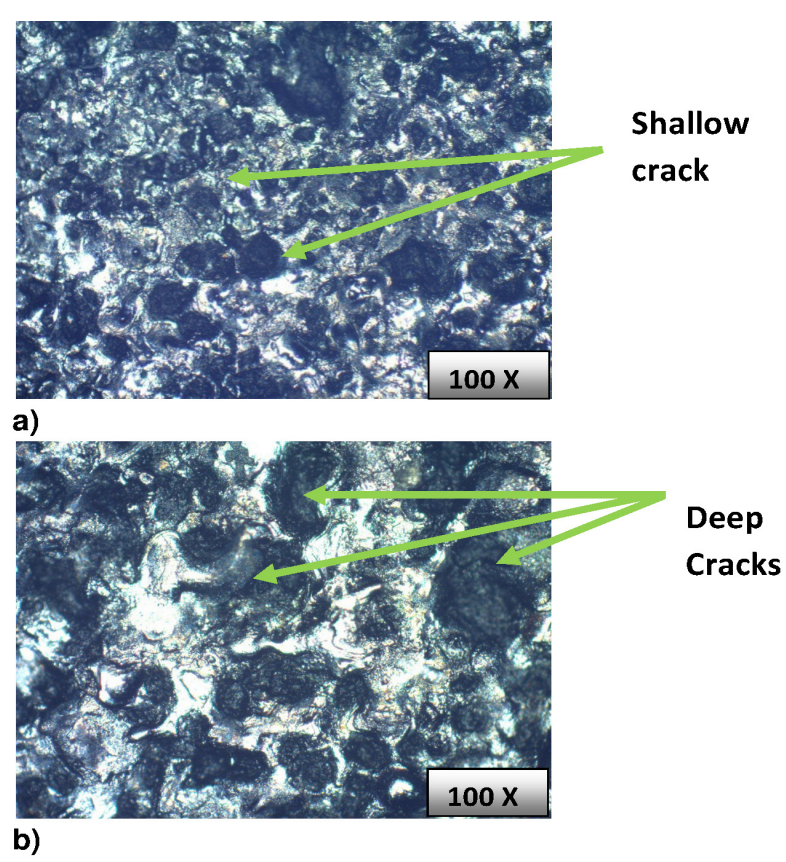

Figure 5. Optical Micrograph of a) PMEDMed surface and b) Concentional EDMed surface

\section{CONCLUSION}

The study attempted to assess the effect of the material property of the workpiece in the machinability in PMEDM process. A custom made PMEDM set-up was made with Aluminium and Mild Steel as workpieces and circular solid copper rod as tool electrode with Alumina at 44 microns as powder additive. The outcome of the experiments is summarised below:

- Among the workpiece materials used, the machinability of Aluminium found to be better than Mild Steel at all the experiment trials, irrespective of the factors and their levels.

- There occurs significant rise in the MRR of PMEDM with Aluminium than in the MRR of the PMEDM with Mild Steel workpiece. $17.52 \%$ is the maximum rise in the MRR of Aluminium PMEDM combination with minimum rise of MRR as $4.1 \%$

- Increase in TWI also found to be higher in PMEDM with Aluminium as workpiece. Maximum rise in TWI was $114.42 \%$ in PMEDM with Aluminium and the minimum increase in TWI has been found to be $4.08 \%$. This further confirms that the material property of the workpiece has considerable effect on its machinability.

- ANOVA analysis indicates that the electrical factors, viz., gap current and duty factor found to 
have predominant effect on MRR as well as TWI in both mild Steel and Aluminium workpieces.

- Main effect plots of data means indicate that all the factors at increasing levels have played a part in achieving higher MRR for both the workpieces.

- However, the rise in gap current also has increased the spark energy which affects the TWI of both the workpiece materials.

- The trend line of MRR plot at all the experimental trials is increasing with some outliers at experimental trial-3, in which the higher gap current with maximum dielectric flushing results in sharp increase in MRR for the materials.

- Also, the increase in the rate flow of powder mixed dielectric has had considerable effect on the machinability process of both the workpieces.

Additionally, the paper provides a scope for carrying out a future experimental investigation on the effect of thermo-physical property of various workpiece materials in enhancing the machinability of the materials in PMEDM process.

\section{REFERENCES}

[1] Kunieda M, et al., Advancing EDM through Fundamental Insight into the Process. CIRP Annals, 2005. 54(2): p. 64 - 87.

[2] Ho, K.H., S.T. Newman, State of the art electrical discharge machining (EDM). International Journal of Machine Tools and Manufacture, 2003. 43(13): p. 1287-1300.

[3] F. T Weng and M.G. Her, Study of the batch production of micro parts using the EDM process. The International Journal of Advance Manufacturing Technology, 2002. 19(4): p. 266-270.

[4] Mohd Abbas, N. et al.: A review on current research trends in electrical discharge machining (EDM). International Journal of Machine Tools and Manufacture, 2007. 47(7): p. 1214-1228.

[5] Tzeng Y. F., Lee C. Y, Effect Of Powder Characteristics On Electrodiscahrge Machining Efficiency. International Journal of Advanced Manufacturing Technology, 2001. 17: p. 586 - 592.

[6] Jeswani, M.L., Effect of the addition of graphite powder to kerosene used as the dielectric fluid in electrical discharge machining. Wear, 1981. 70(2): p. 133-139.

[7] Kansal, H.K., S. Singh, and P. Kumar, Effect of Silicon Powder Mixed EDM on Machining Rate of AISI D2 Die Steel. Journal of Manufacturing Processes, 2007. 9(1): p. 13-22.

[8] Kolli, M., A. Kumar, Effect of dielectric fluid with surfactant and graphite powder on Electrical Discharge Machining of titanium alloy using Taguchi method. Engineering Science and Technology, an International Journal, 2015. 18(4): p. 524-535.

[9] Erden, A., S. Bilgin, Role of Impurities in Electric Discharge Machining, in Proceedings of the TwentyFirst International Machine Tool Design and Research Conference, J.M. Alexander, Editor. 1981, Macmillan Education UK: London. p. 345-350.
[10] Murray, J.W. et al., Physical and electrical characteristics of EDM debris. Journal of Materials Processing Technology, 2016. 229(Supplement C): p. 54-60.

[11] Baseri, H. and S. Sadeghian, Effects of nanopowder TiO2-mixed dielectric and rotary tool on EDM. The International Journal of Advanced Manufacturing Technology, 2016. 83(1): p. 519-528.

[12] Jeavudeen S. et al., Powder Additives Influence on Dielectric Strength of EDM Fluid and Material Removal. International Journal of Machining and Machinability of Materials, 2019. In press.

[13] Houriyeh M. et al, State Of The Art In Powder Mixed Dielectric For EDM Applications. Precision Engineering, 2016. 46: p. 11 - 33.

[14] Yih-fong, T., C. Fu-chen, Investigation into some surface characteristics of electrical discharge machined SKD-11 using powder-suspension dielectric oil. Journal of Materials Processing Technology, 2005. 170(1): p. 385-391.

[15] Talla, G., S. Gangopadhyay, C.K. Biswas, Effect of Powder-Suspended Dielectric on the EDM Characteristics of Inconel 625. Journal of Materials Engineering and Performance, 2016. 25(2): p. 704-717.

[16] Jatti, V.S., S. Bagane, Thermo-electric modelling, simulation and experimental validation of powder mixed electric discharge machining (PMEDM) of $\mathrm{BeCu}$ alloys. Alexandria Engineering Journal, 2018. 57(2): p. 643-653.

[17] Tzeng, Y.-F., C.-Y. Lee, Effects of Powder Characteristics on Electrodischarge Machining Efficiency. The International Journal of Advanced Manufacturing Technology, 2001. 17(8): p. 586-592.

[18] Sevvel P., Jaiganesh V, Impact of Tool Profile on Mechanical Properties of AZ31B Mg Alloy during FSW Using Optimized Parameters. FME Transactions, 2015. 44(1): p. 43-49.

[19] M. Kanthababu, et al.: Experimental Investigations on Pocket Milling of Titanium Alloy Using Abrasive Water Jet Machining. FME Transactions, 2015. 44(2): p. 133-138.

[20] Chakraborty, S., V. Dey, S.K. Ghosh, A review on the use of dielectric fluids and their effects in electrical discharge machining characteristics. Precision Engineering, 2015. 40(Supplement C): p. 1-6.

[21] Srivastava, V., P.M. Pandey, Performance Evaluation of Electrical Discharge Machining (EDM) Process Using Cryogenically Cooled Electrode. Materials and Manufacturing Processes, 2012. 27(6): p. 683-688.

[22] Rajurkar, K.P., S.M. Pandit, Formation and Ejection of EDM Debris. Journal of Engineering for Industry, 1986. 108(1): p. 22-26.

[23] Tilekar, S., S.S. Das, P.K. Patowari, Process Parameter Optimization of Wire EDM on Aluminum and Mild Steel by Using Taguchi Method. Procedia Materials Science, 2014. 5: p. 2577-2584.

[24] Gaikwad, V., V.S. Jatti, Optimization of material removal rate during electrical discharge machining 
of cryo-treated NiTi alloys using Taguchi's method. Journal of King Saud University - Engineering Sciences, 2018. 30(3): p. 266-272.

[25] Peças, P., E. Henriques, Effect of the powder concentration and dielectric flow in the surface morphology in electrical discharge machining with powder-mixed dielectric (PMD-EDM). The International Journal of Advanced Manufacturing Technology, 2008. 37(11): p. 1120-1132.

[26] Prakash, C. et al., Powder Mixed Electric Discharge Machining: An Innovative Surface Modification Technique to Enhance Fatigue Performance and Bioactivity of $\beta$-Ti Implant for Orthopedics Application. Journal of Computing and Information Science in Engineering, 2016. 16(4): p. 041006-041006-9.

[27] Dewangan, S., C.K. Biswas, Optimisation of machining parameters using grey relation analysis for EDM with impulse flushing. International Journal of Mechatronics and Manufacturing Systems, 2013. 6(2): p. 144-158.

\section{УТИЦАЈ ТЕРМО-ЕЛЕКТРИЧНИХ СВОЈС- ТАВА МАТЕРИЈАЛА НА ОБРАДУ ЕЛЕКТРИЧНИМ ПРАЖЫЕЊЕМ СА ПРАШ- КАСТОМ МЕШАВИНОМ}

\section{С. Џеавуден, Х.С. Џаилани, М. Муруган}

Обрада електричним пражњењем са прашкастом мешавином (PMEDM) се сматра изводљивом методом за обраду тврдих и жилавих материјала, али и са значајним термо-електричним својствима. Код PMEDM је утврђено да се обрадивост машином побољшава додавањем адитива у облику финог прашка у размак између електрода. У раду је истражена улога термо-електричних својстава обратка на процес PMEDM. Материјали са израженим термоелектричним својствима, тј. мекани челик и алуминијум су узети за обратке са алуминијумоксидом као адитивом у процесу PMEDM. За експерименте су коришћени Тагучијев ортогонални низ, брзина скидања материјала и индекс хабања алата.

Струја пражњења, радни циклус и брзина протока прашкасте мешавине диелектричне течности узети су за параметре процеса на три новоа са округлим бакарним штапом пречника 12мм као електродом алата. Утицај својстава обратка на обрадивост одређена је стандардном поставком PMEDM процеса. ANOVA и главни ефекат просека података на наведене услове су анализирани. Резултати су значајни јер показују утицај својстава обратка не могућност обрадивости применом процеса PMEDM. 